\title{
Evolution of Biometric Parameters and Oil Fatty Acid Composition of Argan "Argania spinosa L. Skeels" Fruits from Beni- Snassen (Eastern Region of Morocco) During Ripening
}

\author{
Abdelhak Chergui ${ }^{1, *}$, Latifa El Hafid ${ }^{2}$, El Amine Ajal' ${ }^{1}$ Imane Zakariya ${ }^{1}$, Rachid Nejjari', Mohammed Reda Tazi ${ }^{3}$
}

\begin{abstract}
Abdelhak Chergui ${ }^{1, *}$, Latifa El Hafid $^{2}$, El Amine Ajal', Imane Zakariya', Rachid Nejjari', Mohammed Reda Tazi ${ }^{3}$
\end{abstract}

'Laboratory of Pharmacognosy, Mohammed $\checkmark$ University, Faculty of Medicine and Pharmacy, Av. Mohammed Belarabi El Alaoui, BP 6203-Rabat institut-Rabat MOROCCO.

${ }^{2}$ Laboratory of Improving Agricultural Productivity, Biotechnology \& Environment, Mohammed I University, Faculty of Science, Blvd. Mohammed VI, BP 717-Oujda, MOROCCO.

${ }^{3}$ Regional Center of professions of Education and Training of the Orient- Oujda, MOROCCO.

\section{Correspondence}

\section{Abdelhak Chergui}

Laboratory of Pharmacognosy,

Mohammed V University, Faculty of

Medicine and Pharmacy, Av. Mohammed

Belarabi EI Alaoui, BP 6203- Rabat institut-

Rabat, MOROCCO.

Phone no: +212767328440

E-mail: Chergui74@yahoo.fr

History

- Submission Date: 24-10-2020;

- Review completed: 29-11-2020;

- Accepted Date: 10-12-2020.

DOI : 10.5530/pj.2021.13.39

Article Available online

http://www.phcogj.com/v13/i2

Copyright

(C) 2021 Phcogj.Com. This is an openaccess article distributed under the terms of the Creative Commons Attribution 4.0 International license.

\begin{abstract}
Background: Argania spinosa Skeels is an endemic forest essence of Morocco. The argan of the north-east of Morocco remains a virgin subject of study without enough value given to it Objective: The aim of this study is to asses the evolution of biometric parameters and fatty acids composition of the argan fruits from Beni-Snassen region during ripening. Materials and Methods: 4 fruit shapes harvested over seven months were characterized through the measurement of their biometric parameters (size and weight), and their composition of majority fatty acids. Results: the studied argan tree could be classified into two major groups, namely: early-riped trees with oval or oval-apiculate fruits and late-riped trees with fusiform or spherical fruits. When considering the fruits size and weight, the highest values were recorded on late-ripened fruits, more particularly fusiform shapes. The obtained results showed, on one hand, a significant difference in the unsaturated fatty acids, according to the fruit ripeness stage and shapes, being the later significantly affecting the stearic acid content; and on another hand, it was noted an increase of oleic acid content while linoleic acid decreased. In the maturation stage, the spherical shaped fruits were found to have the highest ratio of unsaturated/saturated fatty acids. Conclusion: The results demonstrated the possibility to predict the kernel's weight from the fruit's length. The results also showed the good dietary and nutritional quality of spherical shapes and that the biometric parameters are important criteria for the differentiation of argan tree fruits.
\end{abstract}

Key words: Argan fruits, Beni-Snassen, Biometeric parameters, Fatty acid, Ripeness.

\section{INTRODUCTION}

Argan (Argania spinosa L. Skeels), belonging to the Sapotacea family, is the only one representing the genus Argania in North Africa. ${ }^{1,2}$ It is a relic and endemic forest essence of Morocco ${ }^{3,4}$. The argan tree covers a coastal strip on a large part of the Souss plain in the south -west of Morocco. ${ }^{5,6}$ This species is also present in the eastern area of Morocco $^{7}$, notably in the Beni Snassen mountain and in the eastern Rif., ${ }^{8.10}$ The fruit, commonly known as "argan nuts", is interpreted either as a berry, a "false drupe" $8,10,11$, or a drupe. ${ }^{12}$

At the ecological level, the argan tree contributes to soil fertilization and protection against erosion ${ }^{13}$. It is a thermophilic xerophyte ${ }^{14}$, a soil indifferent species, and can reach an altitude of $1600 \mathrm{~m}^{8}$. In terms of nutrition, argan oil is rich in unsaturated fatty acids, like oleic and linoleic acid ${ }^{15}$, which gives it a high dietary value ${ }^{16}$. At the pharmacological level, oil has hypocholesterolemic and hypotensive effects ${ }^{17,18}$ in addition to cosmetic uses. ${ }^{16}$ At the socioeconomic level, oil is a source of income for 3 million people, the majorly of whom live in rural areas. ${ }^{5,19,14}$ Fruit pulp constitutes also a feeds for livestock (cattle, sheep, goats and camels). ${ }^{20}$

The argan tree of south-western Morocco has been studied in various ways. These studies concern the phenotypic and genetic variability of fruit ${ }^{21,22}$ and the biochemical composition of fruit pulp ${ }^{23}$ and oil. ${ }^{24-26,15}$ However, the argan of the north-east of Morocco remains a virgin subject of study without enough value given to it.

In this regard, this study is a scientific contribution to the evaluation of the performance of the natural argan of Beni-Snassen. The objectives of this work are the following:

- A study of the evolution of the biometric paramerters of 4 types of argan fruits (spherical forms, oval forms, oval apiculate forms and fusiform forms, Figure 1) during maturation.

- A study of the evolution of fatty acids of argan oil, derived from different fruit forms, during maturation.

\section{MATERIALS AND METHODS}

\section{Study area}

The study concerns the fruit of the argan tree (Argania spinosa L. Skeels) from Jbel Takermine (Figure 2); a mountain of the western chain of BeniSnassen (north-east of Morocco) that culminates at $317 \mathrm{~m}$. The Beni-Snassen lands are characterized by a variable lithology; the geological formations are formed, from the bottom to top, by limestone, marsh 


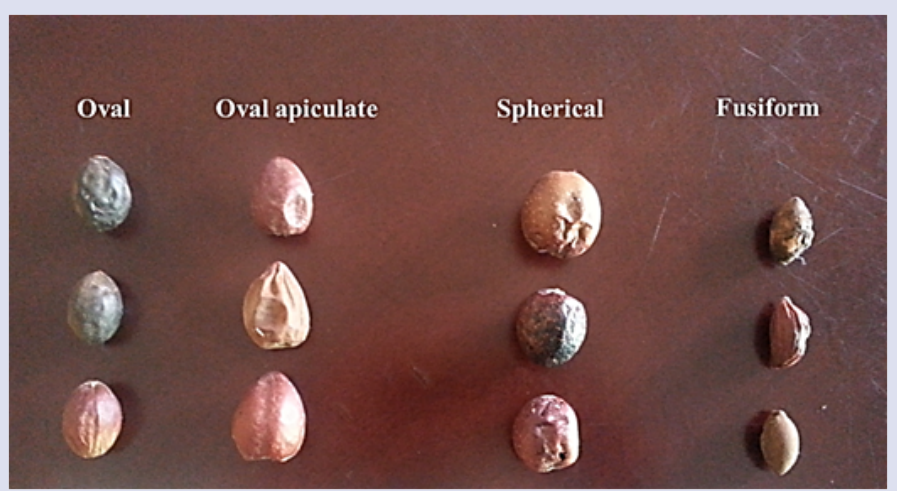

Figure 1: Different forms of argan fruit of Beni-Snassen.

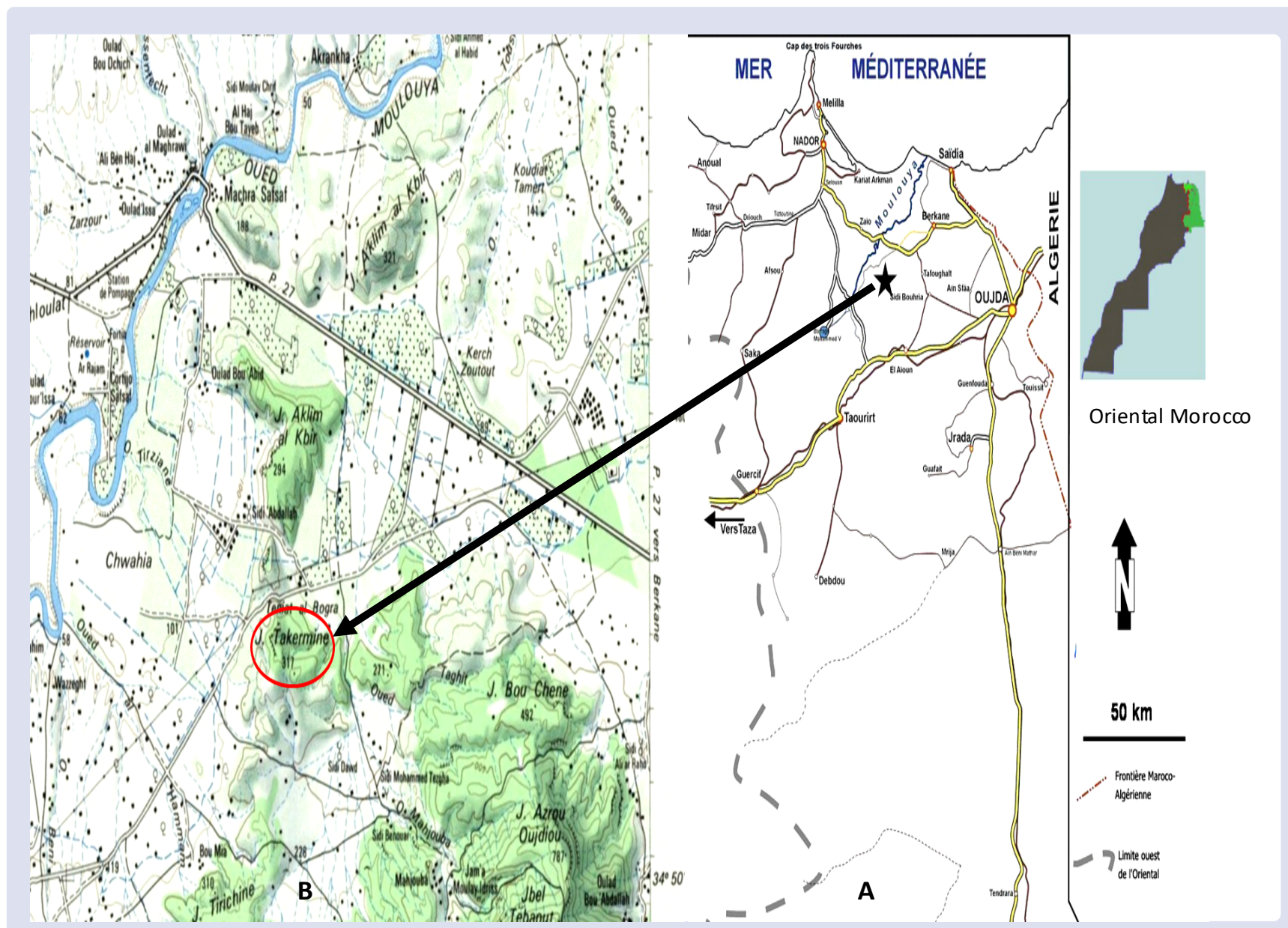

Figure 2: A. general location of study area in Morocco. B. map of Oriental Morocco (1/100000, Mapping direction- Rabat-1974) showing Jbel Takermine (Beni-Snassen mountains).

and sandstone (Oxfordian), dolomitic limestone (KimméridgianPortlandien), conglomerates and greasy limestone (Miocene), gravel alluvium, silt and quaternary collapse. ${ }^{9}$ More particularly, at Jbel Takermine, the argan grows on a rocky limestone substrate. ${ }^{27}$ Annual precipitation ranges from 200 to $400 \mathrm{~mm}^{28}$ The level of vegetation in Jbel Takermine is thermon mediterranean and the bioclimate is higherarid to lower semi-arid ${ }^{29}$, identical to those of the argan of southwestern Morocco. ${ }^{8}$

\section{Sampling plan}

The fruit harvest was carried out according to a stratified sampling plan. Firstly, 12 ripe and fruitful argan trees were selected and divided into
4 stratums according to the fruit shape, namely: 3 trees with spherical fruits, 3 trees with oval fruits, 3 trees with oval apiculate fruits and 3 trees with fusiform fruits. Secondly, random sampling was carried out in each stratum; 30 fruits were randomly harvested from each tree and at various stages of fruit ripening (from the beginning of fruit development, January 2018, till their complete ripening and senescence, July 2018).

\section{Study of the fruit biometric parameters}

The 4 fruit shapes harvested over seven months were characterized through the measurement of their biometric parameters. These measurements concerned the fruit's weight, kernel's weight, almond's 
weight, and the length and width of the fruit and kernel. These biometric measurements are made using a sliding foot and an analytical balance. Each parameter is measured 3 times.

\section{Lipid extraction and analysis}

Lipid extraction was made from almonds according to the Blight \& Dyer method. ${ }^{30} 2 \mathrm{~g}$ of almonds (from a different form of fruits and different maturation stages), were immerged in $10 \mathrm{ml}$ of boiling water for 3 minutes. Once boiled, the almonds were grinded in a mortar in the presence of $15 \mathrm{ml}$ of methanol/chloroform $(2: 1 \mathrm{v} / \mathrm{v})$. Then, $5 \mathrm{ml}$ of chloroform and $10 \mathrm{ml}$ of fixation water were added successively. After centrifugation at $5000 \mathrm{xg}$ for 15 minutes, the chloroform phase was taken and dried under nitrogen, and the residue was taken back into $3 \mathrm{ml}$ of chloroform to form the total lipid extract.

Lipids were then saponified, and their fatty acids were volatilized by methylation. ${ }^{31}$ At $100 \mu$ l of the lipid extract were added $25 \mu$ l of an internal standard (heptadecanoic acid, C17:0) and $3 \mathrm{ml}$ of a methanolsulfuric acid solution $(97.5 / 2.5, \mathrm{~V} / \mathrm{V})$. Subsequently, the sealed tubes were placed in the water bath during $45 \mathrm{~min}$ at $70^{\circ} \mathrm{C}$. After cooling, $3 \mathrm{ml}$ of heptane and $1 \mathrm{ml}$ of distilled water were added. The heptane phase (containing the methyl esters) was then taken, dried under nitrogen and the methyl esters were taken back into $1,5 \mathrm{ml}$ of heptane.

The methyl esters were then separated, identified and quantified by a gas chromatography (GC Varian 3300) with flame-ionization detection (FID). The parameters and operating conditions of the analytical method are summarized as follows: the injector and detector temperatures were set respectively to $240^{\circ} \mathrm{C}$ and $250^{\circ} \mathrm{C}$. Helium was used as carrier gas (pressure: 0,5bar) with a flow rate of $1 \mathrm{ml} / \mathrm{min}$ and an injection volume of $0,1 \mu$ l. A retention capillary column (CP-WAX $52 \mathrm{CB}$ ) with $50 \mathrm{~m}$ in length and $0,32 \mathrm{~mm}$ in diameter was used. During analysis, the oven temperature ramp was gradually increased from $80^{\circ} \mathrm{C}$ to $200^{\circ} \mathrm{C}$ for $20 \mathrm{~min}$.

For each fruit form, the evolution of the majority fatty acids of argan oil (palmitic acid C16:0, stearic acid 18:0, oleic acid C18:1 and linoleic acid C18:2) was followed according to the stage of fruit ripeness (from January 2018 to July 2018). For each test, the extractions and analysis were repeated 3 times.

\section{Statistical analysis}

The statistical analyses are made by the SPSS software (13.5). These included analysis of variance (ANOVA with two factors and an error threshold of 5\%), principal component analysis (PCA), and linear regression.

\section{RESULTS}

\section{Variation in weight of fruit, kernel and almond}

The average weight of the fruit, kernel and almond varies according to the fruit shape and its ripeness stage (Figure 3). This is confirmed by the two-way ANOVA test, which shows a highly significant effect (ANOVA with two factors and an error threshold of 5\%) of the ripening stage and fruit shape on the weights of the fruit, kernel and almond.

The average weight of the 4 fruit shapes increased during fruit ripening; it reached 10,5g for oval fruits, $10,1 \mathrm{~g}$ for oval apiculate fruits, $6,29 \mathrm{~g}$ for spherical fruits, and 11,34g for fusiformfruits. Thus, the weight of the ripe fruit varied between 6,29 and $11,34 \mathrm{~g}$.

At the maturity stage, the average weight of the kernels fluctuated between $1,95 \mathrm{~g}$ (spherical shapes) and 4,97g (fusiform shapes), whereas that of the almonds varied between $0,5 \mathrm{~g}$ (spherical shapes) and $1 \mathrm{~g}$ (oval shapes, oval apiculate shapes and fusiforms shapes).

\section{Variation in fruit and kernel size}

Figure 4 shows that the length and width of the fruit and the kernel vary according to the fruit forms and the fruit's stage of maturity. This is confirmed by the two-way ANOVA test, which shows that there is a highly significant effect (Probability $<0.05$ : significant differences a threshold of 5\%) of the maturity stage and fruit forms on the size of the fruit and the kernel.

The length of the fruit at maturity varies between $21 \mathrm{~mm}$ (spherical shapes) and $50 \mathrm{~mm}$ (fusiforms shapes). The average width of the fruit reaches $24,9 \mathrm{~mm}$ for oval fruits, $16,56 \mathrm{~mm}$ for oval apiculate fruits, $18,02 \mathrm{~mm}$ for spherical fruits and $17 \mathrm{~mm}$ for fusiform fruits. At the maturity stage, the kernel's lenght varied between $17,9 \mathrm{~mm}$ (spherical fruits) and $32,2 \mathrm{~mm}$ (fusiform fruits), whereas the kernel's width varied between $13,03 \mathrm{~mm}$ (oval apiculate fruits) and $16,25 \mathrm{~mm}$ (spherical fruits).

\section{Evolution of the majority fatty acids}

On one side, the analysis of the histogram (Figure 5), showed that the rate of saturated fatty acids (C16:0 and C18:0), for the 4 fruit shapes, remained relatively low and stable during the development of the argan fruit. This was confirmed by the two-way ANOVA test which showed a non-significant effect (threshold of 5\%) of the maturity stage on the saturated fatty acid level.

On another side, the fruit shape appeared to have a highly significant effect only on the C18:0 rates. However, the unsaturated fatty acid rate (C18:1 and $\mathrm{C} 18: 2)$ was relatively high, while being subjected to significant changes during fruit development. This is in agreement with the two-way ANOVA test which showed a highly significant effect (threshold of 5\%) of the maturity

stage on the C18:1 and C18:2 rates. Inversely, the fruit shape appeared to have a weakly significant effect on the C18:2 rates.

At maturity, the ratio of unsaturated fatty acid/saturated fatty acid (UFA/SFA) varies depending on the fruit shape, as shown in Table 1. More particularly, the highest ratio was found in the spherical fruits $(4,07)$, while the lowest ratio was reached in the oval apiculate and fusiform fruits $(3,25$ and 3,34 , respectively). In turn, oval fruits showed an intermediate ratio $(3,55)$.

\section{DISCUSION AND CONCLUSION}

The lower limit of the average fruit weight is close to that reported by M'Hirit \& al..$^{8}$ in the south-western of Morocco, while the upper limit is much lower than that of M'Hirit \& al. ${ }^{8}$ Indeed, according to this author, the average weight of argan fruits was found to vary between 5 and $20 \mathrm{~g}$.

According to the stage of maturity, the argan fruits of the Beni-Snassen can be classified into 2 types of trees: early trees that produce oval and oval-apiculate fruits (maturity at the end of May) and late trees that produce the fusiform and spherical fruits (maturity at the end of July). This difference in maturity stage was also reported by Chernane \& $a .^{22}$ in the argan of southwest Morocco. However, early fruits were represented by oval and spherical shapes, whereas late fruits were represented by oval apiculate shapes and fusiform shapes. ${ }^{22}$ This difference in maturity stage is related to the flowering period, which appears to be dependent on the climatic years ${ }^{32}$, the soil nature ${ }^{22}$ and the tree genotype. ${ }^{33}$

The maximum average weight of kernels was reached in the fusiform shapes, whereas that of almonds was reached in the oval, oval apiculate and fusiform shapes. These results are consistent with those of Charrouf $\&$ Pioch $^{11}$ where the maximum weight of almonds was obtained in case of oval and fusiform fruits. However, the weight of almonds seems to be much higher than in the Agadir area, where it ranges from 0,17 to $0,41 \mathrm{~g} .{ }^{11}$ 


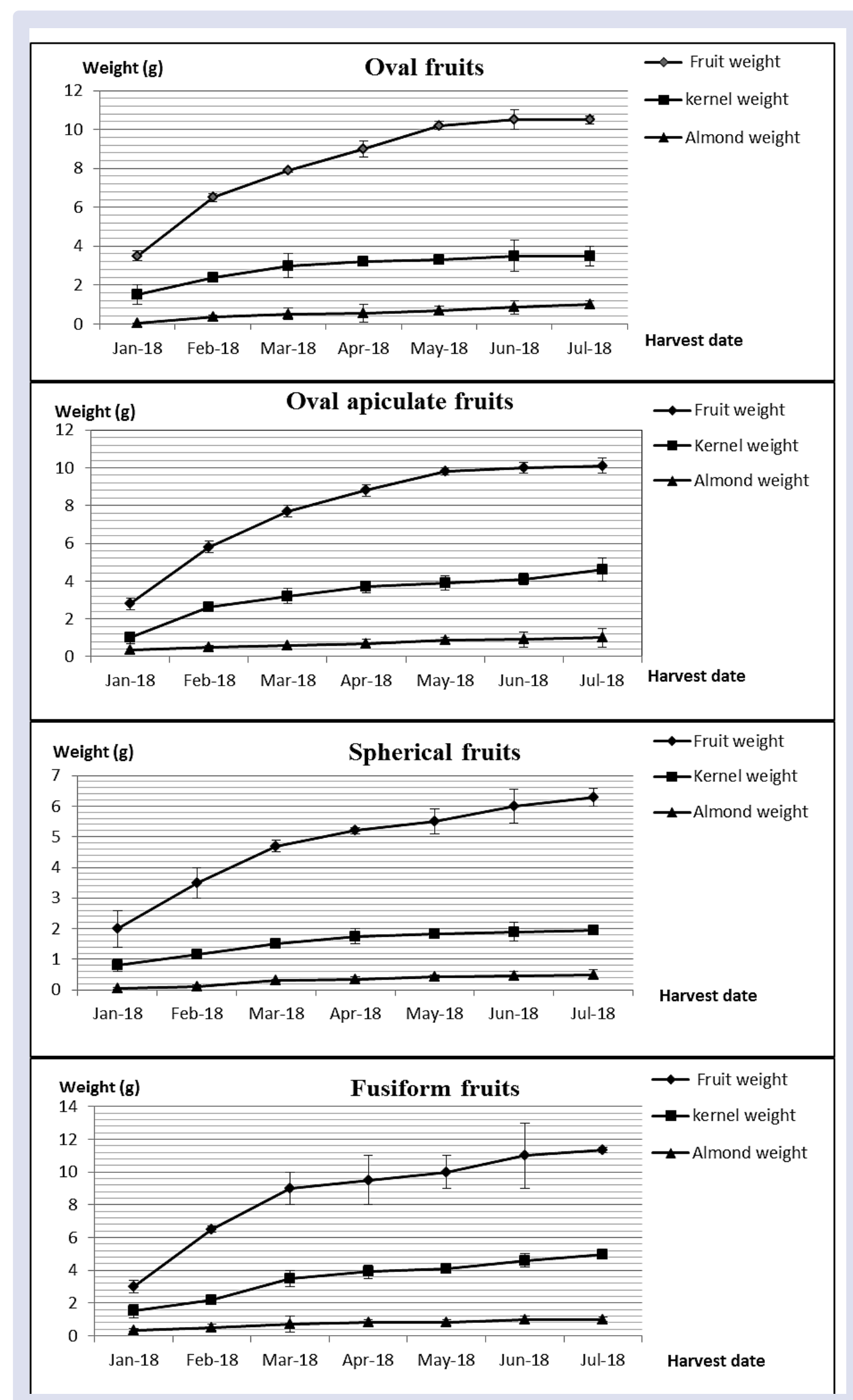

Figure 3: Evolution of the average weight of the fruit, kernel and almond of the argan tree during maturation. 


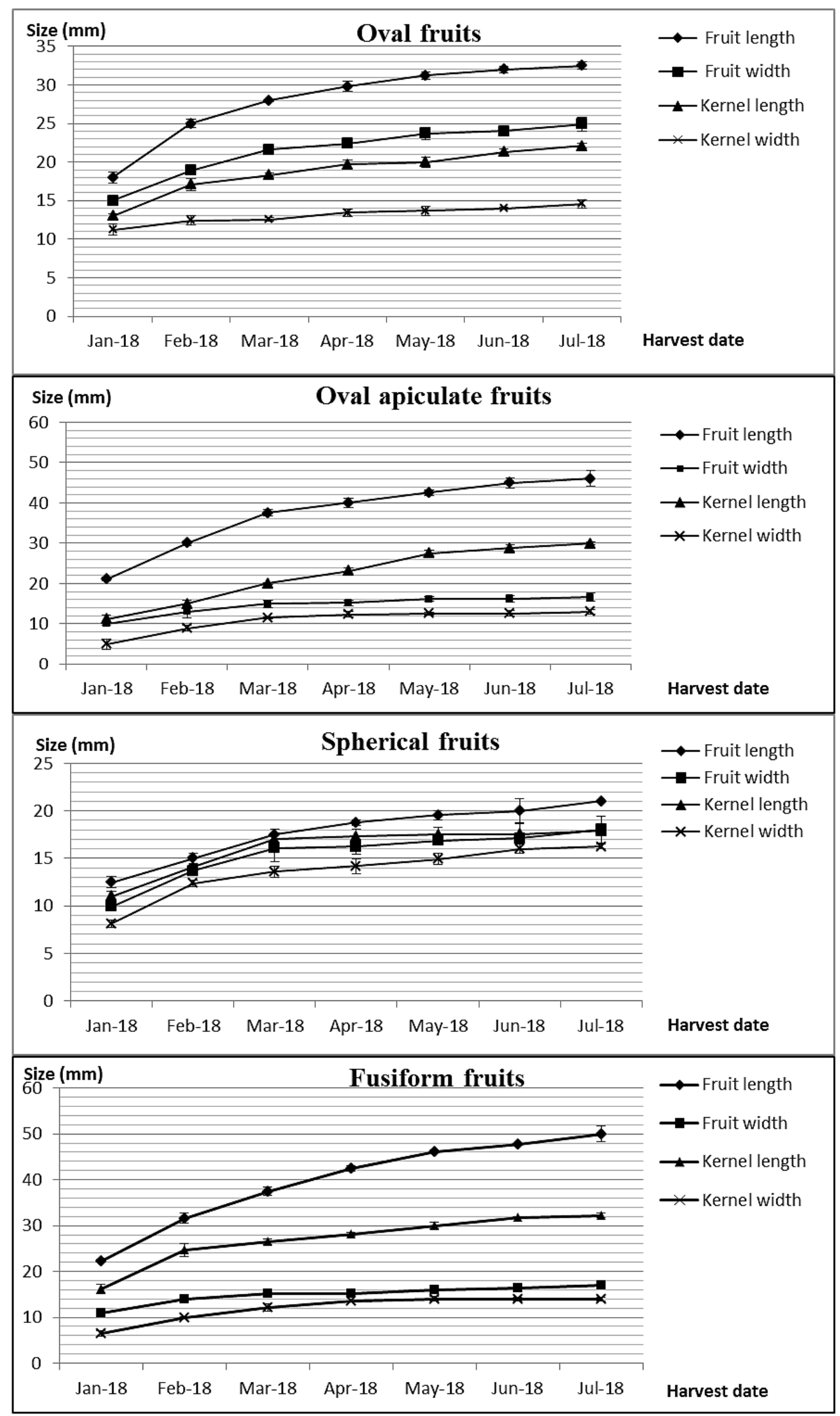

Figure 4: Evolution of size (average values) of fruit and argan kernel during maturation. 


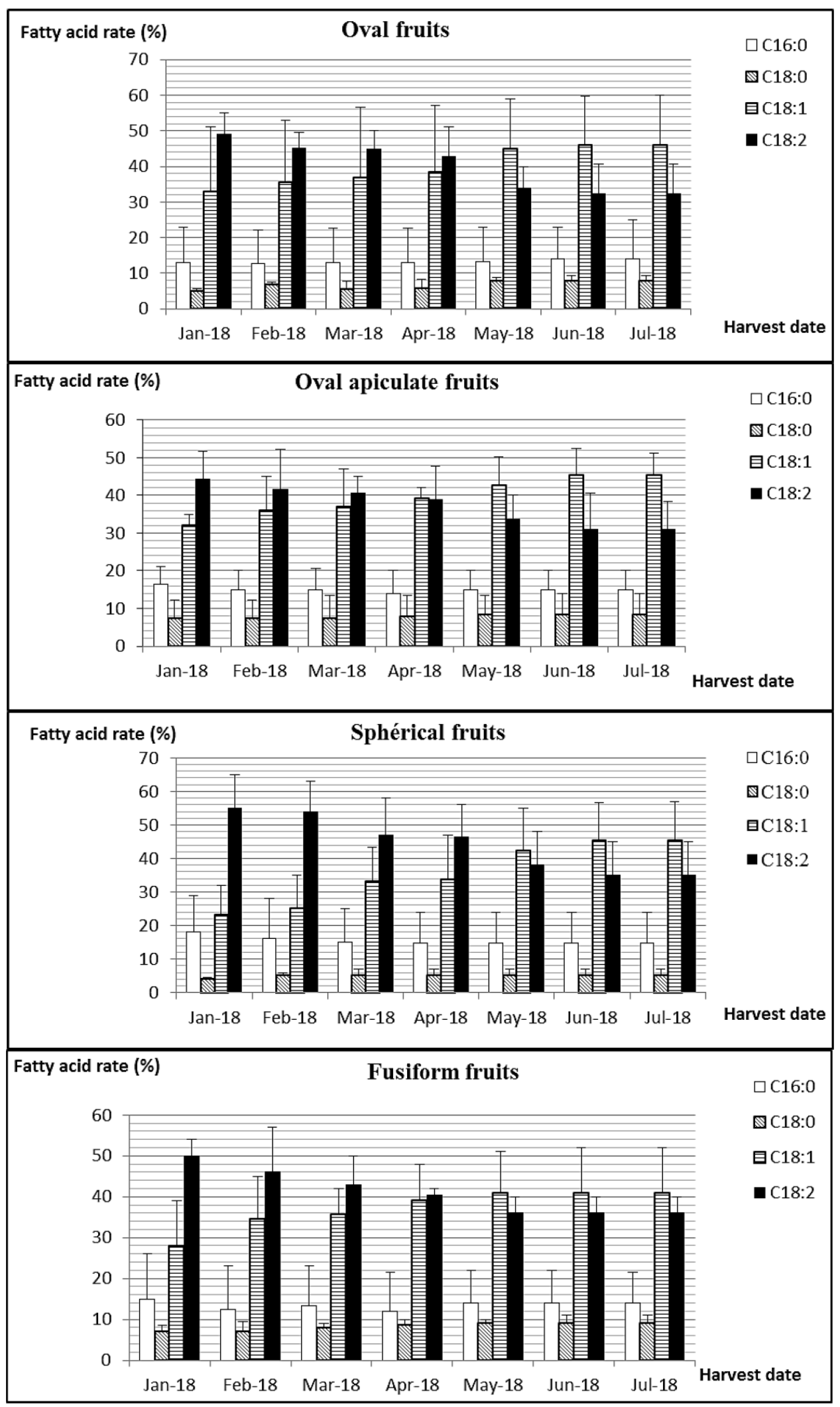

Figure 5: Evolution of the fatty acid rate (average values) of the 4 forms of the argan fruit during maturation. 


\begin{tabular}{|c|c|c|c|}
\hline & $\begin{array}{c}\text { SFA rate } \\
\text { (C16:0 \& C18:0) } \\
\text { (average values) }\end{array}$ & $\begin{array}{c}\text { UFA rate } \\
\text { (C18:1 \& C18:2) } \\
\text { (average values) }\end{array}$ & Ratio of UFA/SFA \\
\hline Spherical fruits & $19,71 \%$ & $80,29 \%$ & 4,07 \\
\hline Oval apiculate fruits & $23,5 \%$ & $76,5 \%$ & 3,25 \\
\hline Fusiform fruits & $23 \%$ & $77 \%$ & 3,34 \\
\hline Oval fruits & $21,95 \%$ & $78,05 \%$ & 3,55 \\
\hline
\end{tabular}

Although the oval and oval apiculate shapes are early fruits, the maximum weight of the fruit and the kernel is relatively low, compared to that of the late fruits. Thus, fusiform fruits appear to be of good quality because they show, at maturity, the maximum weight of the fruit, the kernel and the almond $(11,34 \mathrm{~g} ; 4,97 \mathrm{~g} ; 1 \mathrm{~g}$ respectively).

Fruit growth follows a bisigmoid curve characterized by rapid growth at the beginning (until February-March), a slowdown in growth (towards March-April), a growth recovery and a subsequent stabilization (in May for early fruits and July for late fruits). This growth kinetics is also observed in the argan cultivated in Palestine ${ }^{32}$ and in kernel fruits and grapes. ${ }^{34}$ This kinetics is marked by a period of lower activity; during this intermediate period, kernel lignification and embryo development occur. 22,35

The length of the fruit at maturity varies between 21 and $50 \mathrm{~mm}$. This range is close to that of Ferradous ${ }^{21}$ and Ferradous $\&$ al. ${ }^{36}$ where ripe fruit size ranges between $10-17 \mathrm{~mm}$ and $48,3-50 \mathrm{~mm}$. Similar results were reported by Bani-Aameur \& al. ${ }^{33}$ in the argan of Ait Melloul (southwest Morocco) where the length of the mature fruit varies between $20-25 \mathrm{~mm}$ and $45-50 \mathrm{~mm}$.

At the maturity stage, the width of the fruit varies between 16,56 and $24,9 \mathrm{~mm}$. This width range is similar to that of Charrouf \& Pioch ${ }^{11}$, which report that the width of mature argan fruit of Agadir varies between $15,8 \mathrm{~mm}$ and $23.9 \mathrm{~mm}$.

The maximum length of the fruit and the kernel was reached in the fusiform fruits, whereas the maximum width of the fruit was reached in the oval fruits. For kernels, the maximum width was reached in spherical fruits. Therefore, the fusiform shapes reached the highest ratio of length/with $(2,94)$, which is in good agreement with the results of other authors, such as Zahidi ${ }^{37}$ and Maallah. ${ }^{38}$ However, this ratio is higher than that cited by Chernane \& al. ${ }^{22}$ and Charrouf \& $\operatorname{Pioch}^{11}(2,08$ and 2,07 respectively) for the argan of south-western Morocco.

The evolution of fruit and kernel sizes also distinguishes early fruits, whose growth tends to stabilize around May-June (oval and oval apiculate fruits) and late fruits, whose growth continues until the end of July (spherical and fusiform fruits). These results show differences with the work of Bani-Aameur \& al. ${ }^{33}$, performed on the argan of Ait Melloul. In fact, these authors distinguished 4 groups, namely: the early argan group, the late argan group, the short cycle late argan group and the spread cycle late argan group. Inversely, the Beni-Snassen argan showed only 2 groups, namely: early trees and late trees.

Although the early Beni-Snassen trees are close to the early Ait Melloul trees, in terms of the knotting period (March), the fruits of the former grow in May-June of the following year, while the fruit of the second one grow in April of the following year. Similarly, even if the knotting periods of the late Beni-Snassen trees and Ait Melloul trees are quite similar (July), the periods of fruit ripening appear to be different: in the first case, the ripening occurs in July of the following year, while in the second case it is done in May of the following year. These differences in maturation periods would be due to several factors like climate ${ }^{32}$, soil nature $^{22}$ and tree genotype. ${ }^{33}$
Big size and weight appear to be a character that occurs much more in late fruits, particularly fusiform fruits, than in early fruits. Thus, fusiform fruits can have an interest in terms of quantities of oil and other derivatives.

As is the case with weight, the curve of the evolution of the fruit and the kernel sizes during maturation also shows a bisigmoid tendency. This is different from the work of Chernane $\& a l .^{22}$, where the curve tends to be sigmoid.

The statistical analysis of the different biometric parameters measured by the Durbin-Watson test (Table 2), indicated the possibility of establishing a linear regression between fruit length and kernel weight. In fact, this test gave a value of 1,743 (value between 1,5 and 2,5). Also, the correlation coefficient $(\mathrm{R})$ indicated a good correlation between these two variables $(R=0,93)$, whereas, the coefficient of determination $\mathrm{R}^{2}(0,864)$, suggested that the length of the fruit contributes with $86,4 \%$ in explaining the fruit's weight. Thus, there is a good linear regression between the two variables.

The analysis of the coefficients of the simple linear regression equation (Table 3) showed that the constant and the regression coefficient were significantly different from 0 .

Thus, the model of the simple linear regression can be formulated by next equation:

\section{Kernel weight $=0.102^{\star}$ fruit length -0.321}

The simple linear regression curve is graphically shown in Figure 6. Knowing the length of the fruit, this model allows predicting the weight of the kernel, with an accuracy of $86.4 \%$.

When the fruit is still young, the quantity of C18:2 is greater than that of C18:1. Neverthless, as the fruit matures, the two fatty acids undergo reverse variations; C18:1 increases and C18:2 decreases, then tend to stabilize from May onward in case of the fusiform fruits ( $41 \%$ and $36 \%$ respectively). In other shapes, these two fatty acids tend to stabilize from June (45.29 and 35\% for spherical fruits; $45.86 \%$ and $32.19 \%$ for oval fruits; $45.5 \%$ and $31 \%$ for oval apiculate fruits).

The evolution of C18:1 and C18:2 levels in Beni-Snassen argan fruits is consistent with that reported by Chernane $\&$ al. ${ }^{22}$, which reported an increase of C18:1 and a decrease of C18:2 for all shapes of southwestern Morocco fruit during maturation. The same variations were also observed in olive trees ${ }^{39,40}$, in ivy seeds ${ }^{41}$, and rapeseed..$^{42}$ Negative correlations were also observed between the rate of $\mathrm{C} 18: 1$ and the rate of polyunsaturated fatty acids (C8:2 and C18:3) in sycamore maple cell cultures. ${ }^{43}$ This phenomenon can be explained by the fact that these fatty acids are involved in the formation of phospholipids, which in turn form the structure of newly formed cell membranes. ${ }^{42}$ These lipid changes occur during the maturation phase of the seed. ${ }^{44}$

At ripeness stage, the majority fatty acids of Beni-Snassen argan oil are C16:0 (14 to 15\%), C18:0 (5,1 to 9\%), C18:1 (41 to 45,86\%) and C18:2 ( 31 to $36 \%)$. It's worth to mention that Beni-Snassen's argan oil is oleiclinoleic. ${ }^{45,46}$ Also, according to the Dubois \& $a l .{ }^{47}$ classification, this oil belongs to the monounsaturated fatty acids class, the saturated fatty acids and linoleic acids subclas. 
The proportions of the majority fatty acids of Beni-Snassen argan oil comply with Moroccan industrial standards. ${ }^{48}$ However, Beni-Snassen oil is richer in linolenic acid (C18:3) than in southwestern Morocco: the proportion of $\mathrm{C} 18: 3$ can reach $0,6 \%{ }^{49}$, which is twice the Moroccan standard $(\leq 0,3 \%)$ and twice that marketed in Spain $(0,34 \%$ produced semi-automatically).$^{15}$ Hence, the richness of this essential fatty acid ${ }^{50,51}$ gives Beni-Snassen argan oil important nutritional and dietary roles.

The results showed that the fusiform fruits have good biometric characteristics, in terms of size and weight, but a low ratio of UFA/SFA. However, these fruits may have an interest in terms of quantity of oil and other products. In contrast, spherical fruits are of significant dietary and nutritional value, as they have a relatively high ratio of UFA/SFA.

Statistical analysis of the different quantitative variables studied by the PCA, indicated that there is a statistically acceptable factorial solution (Kaiser-Meyer-Olkin Index $=0,724$, between 0,7 and 0,8 ) (Table 4). Also, the Bartlett's test of sphericity suggested the highly significant correlation between variables (Table 4). This correlation was also confirmed by the correlation matrix (Table 5).

The factorization operation identified 11 components, 3 of which have eigenvalues greater than 1 and cumulate $84,943 \%$ of the explained total variance (Table 6). More particularly, component 1 , after rotation, could explain 4 to 5 variables/11 (42,636\% of the total variance).
The projection of the different variables in the three dimensions formed by the three factorial axis (Figure 7) after rotation, allowed to distinguish 3 groups:

- Component 1: This axis explains the pattern of correlations in group 1. This latter consists of 5 well-correlated biometric variables (Table 5), namely: fruit weight, kernel weight, almond weight, fruit length and kernel length. Then, it explains $42,636 \%$ of the observed total variance and summarizes the previous 5 variables. On this axis, C18:2 is located in the opposite of group 1 (coordinates and correlation, Figure 7). Indeed, C18:2 shows a negative correlation with the group 1 variables (Table 5).

- Component 2: this axis explains the pattern of correlations in group 2. This group is represented by 4 biochemical variables: C16:0, C18:0, C18:1 and C18:2. Then, it explains 21,951\% of the total variance.

- Component 3: This axis explains the pattern of correlations in group 3 . This group is represented by 2 biometric variables, namely: the kernel width and the fruit width. Then, it explains $20,355 \%$ of the total variance. On this axis, C18:2 is located in the opposite of group 3 (coordinates and correlation, Figure 7). Indeed, C18:2 also shows a negative correlation with fruit width and kernel width (Table 5).

It appears that the biometric parameters (group 1 and group 3) provide much of the information on the studied fruits $(62,991 \%$ of the total variance) and constitute important criteria for differentiation of argan

Table 2: Correlation coefficient $(R)$, determination coefficient $\left(R^{2}\right)$ and Durbin-Watson test for the linear regression model.

\begin{tabular}{|c|c|c|c|c|c|}
\hline \multicolumn{6}{|c|}{ Model Summary } \\
\hline Model & $\mathrm{R}$ & R Square & $\begin{array}{l}\text { Adjusted R } \\
\text { Square }\end{array}$ & $\begin{array}{l}\text { Std. Error of } \\
\text { the Estimate }\end{array}$ & $\begin{array}{l}\text { Durbin- } \\
\text { Watson }\end{array}$ \\
\hline 1 & $.930^{a}$ & .864 & .863 & .45330 & 1,743 \\
\hline \multicolumn{6}{|c|}{ a. Predictors: (Constant), Fruit lenght } \\
\hline \multicolumn{6}{|c|}{ b. Dependent Variable: Kernel weight } \\
\hline
\end{tabular}

Table 3: Coefficients of simple linear regression equation.

\begin{tabular}{|c|c|c|c|c|c|c|c|c|}
\hline \multicolumn{9}{|c|}{ Coefficients $^{a}$} \\
\hline \multirow[b]{2}{*}{ Model } & & \multicolumn{2}{|c|}{ Unstandardized Coefficients } & \multirow{2}{*}{$\begin{array}{c}\text { Standardized } \\
\text { Coefficients } \\
\text { Beta }\end{array}$} & \multirow[b]{2}{*}{$t$} & \multirow[b]{2}{*}{ Sig. } & \multicolumn{2}{|c|}{$95,0 \%$ Confidence Interval for $B$} \\
\hline & & B & Std. Error & & & & Lower Bound & Upper Bound \\
\hline \multirow[t]{2}{*}{1} & (Constant) &,- 321 & .146 & & $-2,197$ &, 031 &,- 612 &,- 030 \\
\hline & Fruit lenght &, 102 &, 004 &, 930 & 22,869 &, 000 & .093 & .111 \\
\hline
\end{tabular}

Table 4: KMO and Bartlett's Test.

\begin{tabular}{ccc}
\hline \multicolumn{2}{c}{ Kaiser-Meyer-Olkin Measure of Sampling Adequacy. } &, 724 \\
\hline & Approx. Chi-Square & 1097,834 \\
\multirow{3}{*}{ Bartlett's Test of Sphericity } & df & 55 \\
& Sig. &, 000 \\
\hline
\end{tabular}




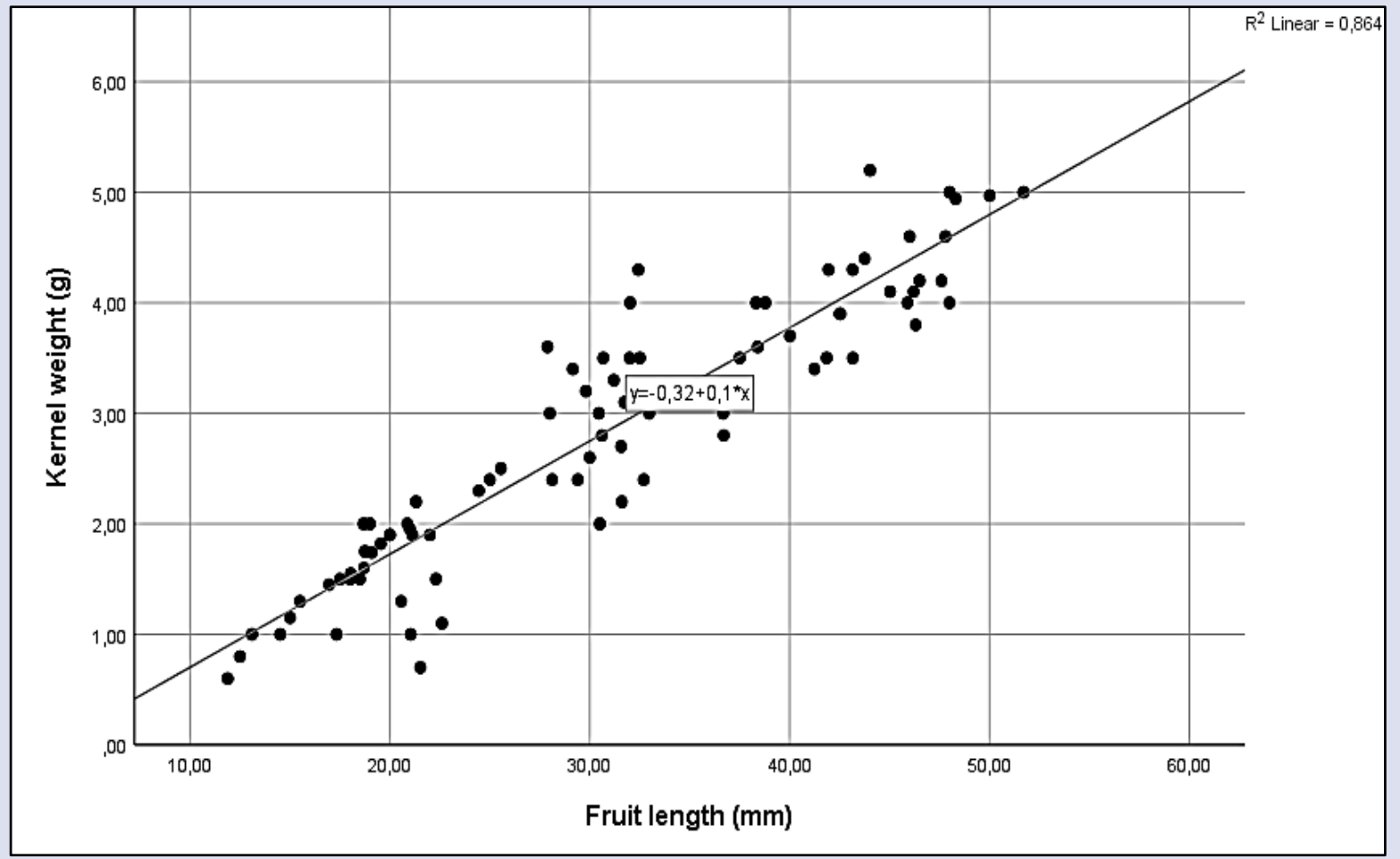

Figure 6: Linear regression curve and equation of kernel weight by fruit length.

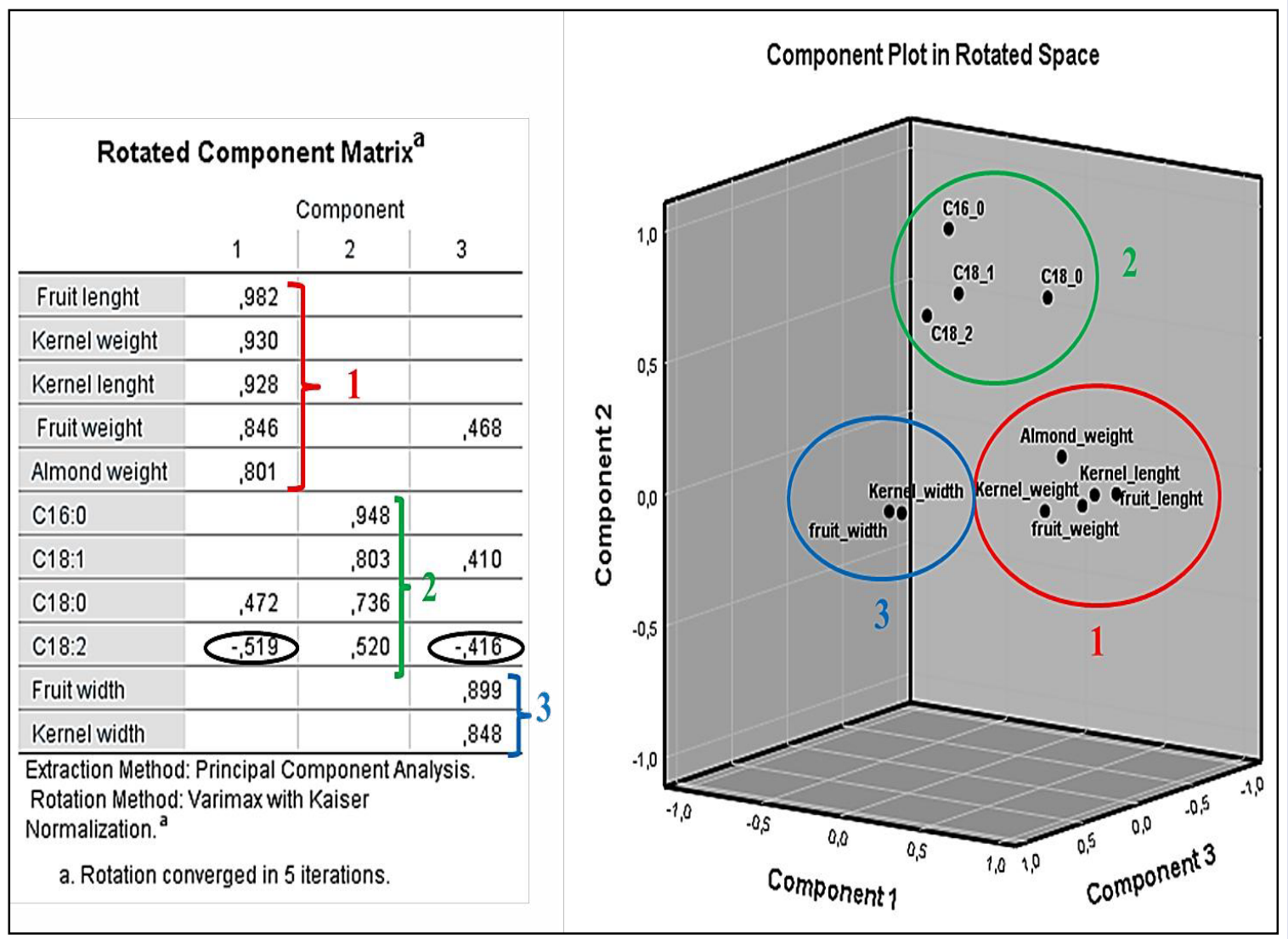

Figure 7: Components plot in rotated space and rotated component matrix. 


\begin{tabular}{|c|c|c|c|c|c|c|c|c|c|c|c|c|}
\hline \multicolumn{13}{|c|}{ Correlation Matrix } \\
\hline & & Fruitweight & Kernel weight & $\begin{array}{l}\text { Almond } \\
\text { weight }\end{array}$ & Fruitlenght & Froitwitth & Kermel lenght & Kernel with & $C 16: 0$ & $C 18: 0$ & C18.1 & C18.2 \\
\hline \multirow[t]{11}{*}{ Correlation } & Fruitweight & 1,000 & 911 &, 758 & 856 & .611 & .846 &, 536 & .068 & 396 & .416 & .562 \\
\hline & Kernel weight & 911 & 1,000 & .799 & 930 & .394 & .880 & 394 & .051 & .402 & 362 & .520 \\
\hline & Almond weight &, 758 &, 799 & 1,000 &, 747 & .369 &, 723 & .337 & .108 & .464 & .478 & ; 417 \\
\hline & Fruitlenght & .856 & 930 &, 747 & 1,000 &, 181 & 925 & .222 & .049 & .489 & 314 & -472 \\
\hline & Fruitwidth & .611 &, 394 & 369 & .181 & 1,000 & .218 & .657 & 051 & .082 & 384 & .377 \\
\hline & Kernellenght & .846 & .880 &, 723 & .925 & .218 & 1,000 &, 414 & .040 & .448 & 337 & $; 445$ \\
\hline & Kernel width &, 536 &, 394 & .337 & .222 & .657 & .414 & 1,000 & .043 & .059 & 371 & .356 \\
\hline & $C 16: 0$ &., 068 & 051 &, 108 & .049 & .051 & .040 & .043 & 1,000 & .539 &, 753 & .506 \\
\hline & $C 18.0$ & 396 &, 402 & .464 & .489 & .082 &, 448 &, 059 &, 539 & 1,000 &, 608 &, 180 \\
\hline & C18:1 & .416 &, 362 & .478 &, 314 &, 384 &, 337 &, 371 &, 753 & .608 & 1,000 & .024 \\
\hline & C18.2 & .562 & .520 & ; 417 & ; 472 & -377 & ; 445 & .356 &, 506 & , 180 & .024 & 1,000 \\
\hline
\end{tabular}

Table 6: Eigen values of different components.

\begin{tabular}{|c|c|c|c|c|c|c|c|c|c|}
\hline \multirow[b]{3}{*}{ Component } & \multicolumn{9}{|c|}{ Total Variance Explained } \\
\hline & \multicolumn{3}{|c|}{ Initial Eigenvalues } & \multicolumn{3}{|c|}{ Extraction Sums of Squared Loadings } & \multicolumn{3}{|c|}{ Rotation Sums of Squared Loadings } \\
\hline & Total & \% of Variance & Cumulative \% & Total & \% of Variance & Cumulative $\%$ & Total & $\%$ of Variance & Cumulative $\%$ \\
\hline 1 & 5,564 & 50,578 & 50,578 & 5,564 & 50,578 & 50,578 & 4,690 & 42,636 & 42,636 \\
\hline 2 & 2,322 & 21,111 & 71,689 & 2,322 & 21,111 & 71,689 & 2,415 & 21,951 & 64,588 \\
\hline 3 & 1,458 & 13,254 & 84,943 & 1,458 & 13,254 & 84,943 & 2,239 & 20,355 & 84,943 \\
\hline 4 &, 494 & 4,495 & 89,438 & & & & & & \\
\hline 5 &, 419 & 3,809 & 93,247 & & & & & & \\
\hline 6 & .298 & 2,713 & 95,960 & & & & & & \\
\hline 7 & .257 & 2,339 & 98,299 & & & & & & \\
\hline 8 & .077 &, 702 & 99,002 & & & & & & \\
\hline 9 &, 055 & .504 & 99,506 & & & & & & \\
\hline 10 & .036 &, 329 & 99,835 & & & & & & \\
\hline 11 &, 018 &, 165 & 100,000 & & & & & & \\
\hline
\end{tabular}

tree fruits. However, the biometric paramaters are weakly correlated to the proportions of oleic and linoleic acids (Table 5).

The results of this work constitute a scientific contribution to the evaluation of the performance of the natural argan originating from Ben-snassen forest.

The biometric study showed that the maturity of the different fruit shapes occurs between May and July, and that the fusiform fruit has the best biometric qualities. This type of fruit can be of interest in terms of quantity of oil and other products. The study showed that a good prediction of the weight of the kernel can be made from the length of the fruit.

Furthermore, the majority fatty acid profile of Beni-Snassen oil is comparable to that of southwestern Morocco (oleic-linoleic oil). The results also showed the good dietary and nutritional quality of spherical shapes due to their good ratio of unsaturated/saturated fatty acids.

The biomteric parameters are the most important criteria for differentiation of argan tree fruits. However, these parameters are weakly correlated to the proportions of oleic and linoleic acids. 


\section{COMPETING INTEREST}

The author(s) declare that they have no competing interests.

\section{ACKNOWLEDGMENT}

We would like to express our very sincere thanks to all the partners who are collaborating with us on this project. We take profit from this opportunity to thank all the scholars who kindly contribute in revising and correcting this manuscript.

\section{REFERENCES}

1. Silvia LF, Sandra PL, Ana U. The Potential Growing Areas for Argania spinosa (L.) Skeels (Sapotaceae) in Argentinean Drylands. International Journal of Agronomy.2018;2018:1-10.

2. Mohamed Seif Allah K. Caracterisation de I'arganier (Argania spinosa L.) en Algerie et impact de la salinite. Thèse, Faculté des Sciences de la Nature et de la Vie, Université Des Frères Mentouri, Constantine, Algérie, 2016.

3. Hicham B, Abdelkader E, Maria Dolores H, MD Herrea G, Maria AS, Naïma BK, et al. Hypolipidemic and hypocholesterolemic effect of argan oil (Argania spinosa L.) in Meriones shawirats. J of Ethnopharmacol. 2003;8 (1):15-8.

4. Zoubida C, Domonique G. Ethnoeconomical, ethnomedical, and phytochemical study of Argania spinosa (L.) Skeels. Journal of Ethnopharmacology. 1999;67:7 14.

5. Zoubida C, Dominique G, Abdelfettah D. L'arganier, un atout pour le maroc. Biofuture. 2002;220:54-7.

6. Mohamed Louay M, Mimoun M, Ilham M, Imane A, Ouafa B. Multiplication végétative de l'arganier (Argania spinosa) par bouturage et par greffage. Rev Mar Sci AgronVet. 2017;5(4):428-36.

7. Louis E. Le domaine naturel de l'arganier.Bulletin de la Société Botanique de France. 1925;72:770-4

8. Omar M, Mohamed B, Fouad B, Sidi Mohamed E, M'Hamed B. L'arganierune espèce fruitière- forestière à usage multiple. Margada, Belgique: Sprimont; 1998.

9. Mohammed Reda T, Abdelbasset B, Benyounes H.Esquisse cartographique de I'aire de l'arganier Argania spinosa (L.) Skeels au Maroc nord-oriental. Bulletin de l'Institut scientifique, Rabat. 2003;25:53-5.

10. Nada R. L'Arganier arbre du sud-ouest marocain, en péril à protéger. Thèse, Faculté de Phramacie, Université de Nantes, Fance, 2003.

11. Zoubida C, Daniel P. Valorisation du fruit d'arganier, Huile d'argan : qualité, diversification. "Appui à l'amélioration de la situation de l'emploi de la femme rurale et gestion durable de l'arganeraie dans le sud-ouest du Maroc ». Maroc Projet UE / MEDA / ADS ; 2009.

12. Hassan F. L'Agdal dans la dynamique des systèmes agraires des arganeraies des Haha (Haut-Atlas Occidental,Maroc).Openedition journals. 2011. Available from: http://journals.openedition.org/etudescaribeennes/5569.

13. José AC, Mirela R, Maria Del Carmen PC, Mohamed B, Abdelaziz E, Angeles G. Characterization of artisanally and semiautomatically extracted argan oils from Morocco. Eur J Lipid Sci Technol. 2008;110:1159-66.

14. Ahmed W, Abdelaziz M, Fouad M. Effet de l'irrigation sur la reprise des jeunes plants d'arganier après transplantation au terrain. Rev Mar Sci Agron Vét. 2018;6(4):437-45.

15. Ascension R, Isabel S, Manuel O, Rafael G, Luis L, Carmen CV.Characterization of Fatty Acid Profile of Argan Oil and Other Edible Vegetable Oils by Gas Chromatographyand Discriminant Analysis. Journal of Chemistry. 2014. Available from: http://dx.doi.org/10.1155/2014/843908

16. Travis JL, Abdellah A, Deborah C, Nicholas M, Maliha N. Booming markets for Moroccanargan oil appear to benefit some rural households while threatening the endemic argan forest. PNAS. 2011;108:13963-8.

17. Mounia C, Hichan B, Anas D, Ahmed A, Abdelouahed K.Argan oil: which benefits on cardiovascular diseases? Pharmacological Research. 2006;54(1):1-5.

18. Souad S, Merien B, Darine K, Nassima B, Nassima S, Abdelhafed N, et al. Argan oil improves surrogate markers of CVD in humans. British Journal of Nutrition. 2012;107(12):1800-5

19. Zoubida C, Dominque G. Phenols and polyphenols from Argania spinosa. Américain journal of Food Technology. 2007;2(7):679-83.

20. Sandret FG. La pulpe d'argan: composition chimique et valeur fourragère, variation au cours de la maturation. Ann Rech Forest (Maroc).1957;4:153-77.

21. Abderrahim F. Diversité génétique de quelques caractères morphologiques du fruit et de la graine d'arganier (Argania spinosa (L.) Skeels). Mémoire du Diplôme des Etudes Supérieures (DES), Faculté des Sciences, Université lbnou Zohr, Maroc, Agadir, 1995.
22. Halima C, Abdelatif $H$, Ismail E, Hamid A. Evolution of biometric parameters and fatty acid composition of oil from four types of fruits of Argania spinosa L. skeels during maturation. Agrochimica. 2000;44(5-6):180-96.

23. Zoubida C, Souad FT, Francis R. Occurrence of Erythrodiol in Argania spinosa, Al Biruniya. 1990;6(2):135.

24. Mohammed R. Composition chimique de I'huile d'argane "vierge ". Cahiers Agricultures. 2005;14(5):461-5.

25. Said G, Hicham H, Dominique G, Aziza H, Bertrand M, Zoubida C. Oxidative stability of edible argan oil: A two-year study. Food Science and Technology. 2011;44:1-8.

26. Zoubida C. L'Arganier, patrimoine marocain etmondial à sauvegarder et à protéger : mini-review sur la composition chimique de ses produits et sur les essais devalorisation ». Al Biruniya, Revue Marocaine de Pharmacognosie. 1995;2:119-26

27. Khalil F, Yahya R, Azzouz B, Hamid M, Abdelbasset B. Cartographie de l'aire de répartition de l'arganier (Argania spinosaL. Skeels) dans la région orientale du Maroc par le G.P.S. combinéau S.I.G. Revue "Nature \& Technologie ". C-Science de l'Environnement. 2015;12:16-24.

28. Schéma de développement et d'aménagement régional (SDAR) de la région de I'Oriental. Maroc: Ministère de I'Aménagement du Territoire de l'Eau et de l'Environnement ; 2000.

29. Luis E.Une classification biogéographique des climats. Fac.Sci. Montpellier Rec Trav Labo Bot Géol Zool Série Bota. 1955;3-43.

30. Graham B, Williams JD. A rapid method of total lipid extraction and purification Can J Biochem Physiol. 1959;37:911-7.

31. Jean PC, Jean PD. Adaptation of macroscale method to the micro-scale for fatty acid methyl transesterification of biological lipid extract. J Chromatogr 1978;151:348 -90.

32. Avinoam N, Vered I, Yosef M. Phenology, breeding system and fruit development of Argan (Argania spinosa, Sapotaceae) cultivated in Palestine. Economic Botany.1998;52:161-7.

33. Fouzia BA, Latifa L, Pascal D. Maturation et chute des fruits de l'arganier. Actes Inst Agron Vet (Maroc). 1998;18(3):151-8.

34. Jean PN, Charlotte P, Colette N, Nelson JS. Natural Growth Substances in Concord and Concord Seedless Grapes in Relation to Berry Development. Amer J Bol.1960;47:66-76.

35. René HR, Robert E, Claude L. Physiologie végétale. 2-Développement. Dunod Paris; 2000.

36. Abderrahim F, Fouzia BA, Pascal D. Diversité génétique du fruit et de la graine del'arganier. In Birouk A. \& Rajdali M. Ressources phytogénétiques et développement durable. Actes Editions 1997. Rabat ; 1997. p. 310-324.

37. Abdelaziz Z. Analyse de la variabilité de la feuille, de la croissance et de la ramfication de la tige et de la racine des plantules d'arganier (Argania spinosa $\mathrm{L}$. Skeels), Effet du Fusarium Oxyporum sur la fonte de semis d'arganier. Thèse, Faculté des sciences appliquées, Université Ibn Zohr, Agadir, Maroc, 2004

38. Abderrahim M. Contribution à l'étude de la composition des huiles et tourteaux des graines de quelques plantes marocaines. Thèse, Faculté des sciences de Marrakech, Université Cadi Ayyad, Maroc, 1992.

39. Giorgio P, Franco F., Maurizio S. M, Gian F M. Agro-climatic factors and characteristics of the composition of virgin olive-oils. Acta Hortic. 1990;286:47780.

40. Hamid A, Abderraouf E, Abdellatif H. Fatty acids and sterols evolution during the ripening of olives from the Moroccan Picholine cultivar. Grasas y Aceites. 1998;49 (5-6):405-10.

41. Michèle G. Biosynthèse des acides gras au cours du développement du fruit et de la graine du lierre. Phytochemistry.1971;10(6):1261-73.

42. Khaled S, Sadok B, Habib K. Évolution des tocophérols en relation avec les acides gras insaturés au cours de la maturation des graines de colza de printemps (Brassica napus L.). C. R. Biologies. 2007;330:55-61.

43. Coline M, Morgane M, Mathilde C, Catherine A, Valérie G, Eric M, et al. Levels of polyunsaturated fatty acids correlate with growth rate in plant cell cultures. Scientific Reports; 2015 oct. Report n 5:15207.

44. Sébastien B, Loïc L.Compared analysis of the regulatory systems controlling lipogenesis in hepatocytes of mice and in maturing oilseeds of Arabidopsis. in Comptes Rendus Biologies. 2008;331(10):737-45.

45. Hanae E, Dom G, Clément D, Zoubida C. Therapeutic potential of argan oil: a review. Journal of Pharmacyand Pharmacology. 2010;62(12):1669-75.

46. Said G.Contribution à la valorisation de l'huile d'argane : Influence de l'origine du fruit (terroir, forme) et de la méthode d'extraction sur la composition chimique, les caractéristiques organoleptiques et la stabilité de l'huile d'argane. Thèse, Faculté des Sciences, Université Mohammed V, Rabat, Maroc, 2012.

47. Verginie D,Sylvie B, Michel L, Jacques F, Michel P. Fatty acid profiles of 80 vegetable oils with regard to theirnutritional potential. European Journal of Lipid Science and Technology. 2007;109(7):710-32. 
Chergui, et al:: Evolution of Biometric Parameters and Oil Fatty Acid Composition of Argan "Argania spinosa L. Skeels" Fruits from Beni-Snassen (Eastern Region of Morocco) During Ripening

48. Moroccan Standards 08.5.090 Argan Oil Specifications; Minister of Industry, Energy and Mines, 2003. Morocco: Rabat; 2003

49. Latifa E, Said M, Mimoun K, Mohammed M, Abdelhak C. Effects of storage conditions on Argan oil quality of Beni Snassen natural forest. Research Journal of Pharmaceutical, Biological and Chemical Sciences. 2014;5(2):373-80.
50. Michel $\mathrm{P}$, Monique H. Abrégé de matière médicale: Pharmacognosie. Masson: Paris; 1980.

51. Ina $P$, Linda $M$, Roman $P$, LIwellyn MA. Frying performance of genetically modified canola oils. J Am Oil Chem Soc. 1999;76:627-32.

\section{GRAPHICAL ABSTRACT}
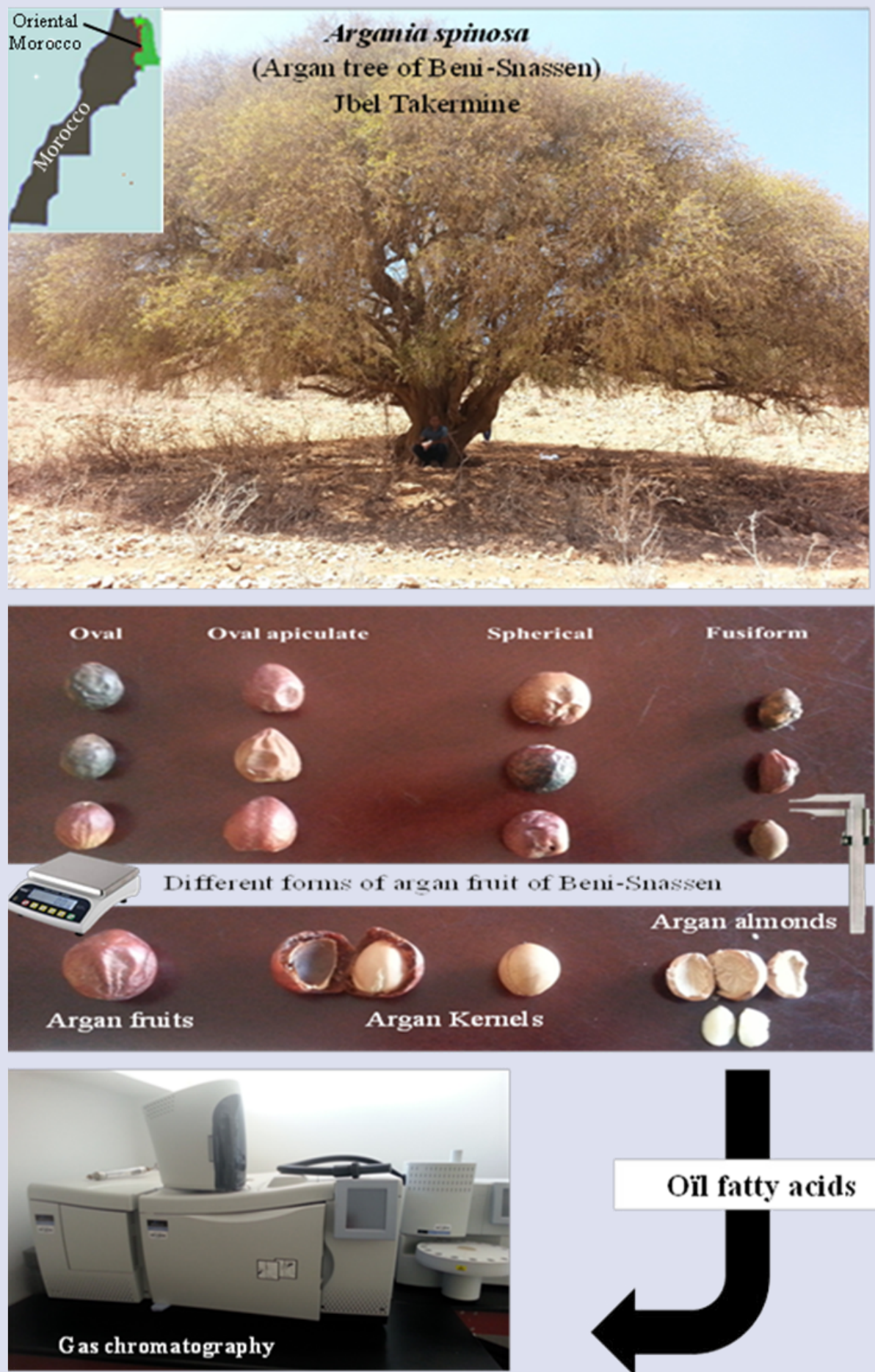

Oïl fatty acids 


\section{ABOUT AUTHORS}

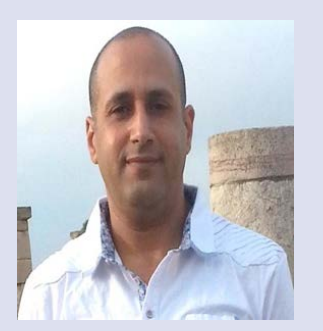

\section{Abdelhak CHERGUI, Professor-Researcher}

Professor at the Faculty of Medicine and Pharmacy of Rabat (Morocco). The author Abdelhak CHERGUI is professor-researcher at the Faculty of Medicine and Pharmacy at Mohammed V University in Rabat (laboratory of Pharmacognosy). He is specialist in plant biology \& ecophysiology and systematic botany of aromatic and medicinal plants. He is also associate professor in Biology \& Geology and Teacher trainer in pedagogy and didactics of Life and Earth Sciences. The author has published several research papers and books.

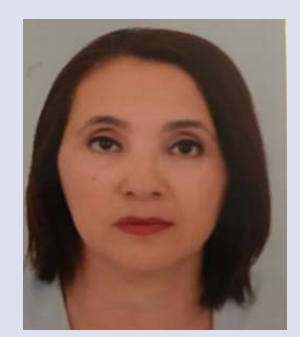

\section{Latifa EL HAFID, Professor-Researcher}

Professor at the Faculty of Sciences-Oujda (Morocco)

The author Latifa EL HAFID is a professor and researcher at the Faculty of Sciences at Mohamed $1^{\text {st }}$ University in Oujda, Morocco, since 1990. She is a specialist in Plant biology and systematic botany of medicinal plants. She supervised several doctoral theses and authored several scientific articles and books.

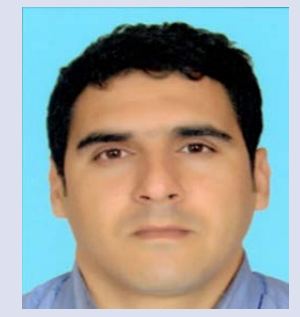

\section{El Amine AJAL, Professor-Researcher}

Professor at the Faculty of Medicine and Pharmacy of Rabat (Morocco). Specializing in biodiversity, natural products chemistry, and Food Sciences and Technology. Dr AJAL now works as ProfessorResearcher at Pharmacognosy Department within the Faculty of Medicine and Pharmacy of Rabat. His field of expertise refers to the development and optimization of analytical methods and their application for the evaluation of different aspects of food quality and authenticity, in particular in the field of olive oil and pomegranate. Moreover, Professor AJAL is the author or co-author of multiple research papers in reviewed international journals relating to Food Science.

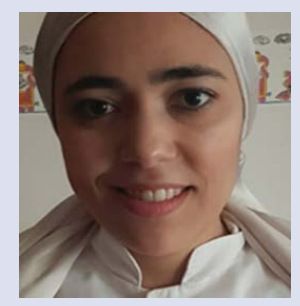

\section{Imane ZAKARIYA, Professor-Researcher}

Professor at the Faculty of Medicine and Pharmacy of Rabat (Morocco). The author Imane ZAKARIYA is Professor Researcher at the faculty of medicine and pharmacy-Rabat (Pharmacognosy laboratory). Her focus is based on the use of natural compounds to have application in health field. She was awarded her PhD in 2007 from the University Mohammed V Morocco, afterwards in 2012, she obtained her specialty diploma in clinical and hospital pharmacy from the same faculty. She has published many articles in international journals, with interest of clinical pharmacy and pharmacognosy.

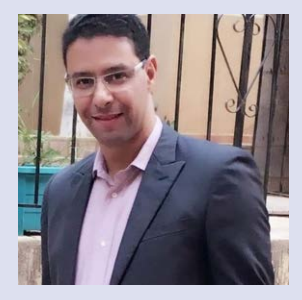

\section{Rachid NEJJARI, Professor-Researcher}

Professor at the Faculty of Medicine and Pharmacy of Rabat (Morocco). The author Rachid NEJJARI is professor-researcher at the Faculty of Medicine and Pharmacy at Mohammed V University in Rabat (laboratory of Pharmacognosy). He is Pharmacist Specialist on clinical pharmacy and Director of Pedagogy and Research Units of pharmacognosy. Professor Rachid NEJJARI is also the Head of Hospital Pharmacy Department in the Souissi Maternity Hospital (University Hospital Center of Ibn Sina-Rabat). The author has supervised several doctoral theses and authored several scientific articles and books.

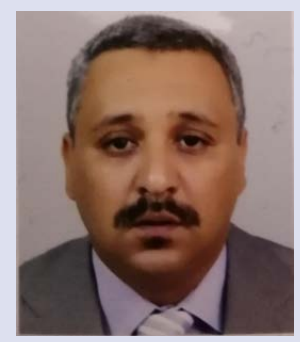

\section{Mohammed REDA TAZI, Professor-Researcher}

Professor at the Regional Center of the Trades of Education and Training of the Oriental- Oujda (Morocco). The author Mohammed REDA TAZI is professor-researcher at the Regional Center of the Trades of Education and Training of the Oriental(Oujda).He is specialist in plant biology \& ecophysiology and associate member in the Laboratory of Improving Agricultural Productivity, Biotechnology \& Environment (team: Water, Environment \& health) at the Faculty of Sciences at Mohamed $1^{\text {st }}$ University (Oujda).

The author is also Teacher trainer in pedagogy and didactics of Life and Earth Sciences. The author has published several research papers.

Cite this article: Chergui A, El Hafid L, Ajal EA, Zakariya I, Nejjari R, Tazi MR. Evolution of Biometric Parameters and Oil Fatty Acid Composition of Argan "Argania spinosa L. Skeels" Fruits from Beni- Snassen (Eastern Region of Morocco) During Ripening. Pharmacog J. 2021;13(2): 296-308. 